\title{
Synthesis of a 1,3-Bridged Macrobicyclic Enyne via Chemoselective Cycloisomerization Using Palladium-catalyzed Alkyne-Alkyne Coupling
}

Barry M. Trost*, James T. Masters, Franck Le Vaillant, and Jean-Philip Lumb

\author{
Supporting Information
}

\section{Table of Contents}

\footnotetext{
1) Copies of ${ }^{1} \mathrm{H}$ and ${ }^{13} \mathrm{C}$ NMR Spectra................................ Pages 2-14

2) Full-size Thermal Ellipsoid Plot for Crystal Structure of Compound 9......... Page 15

3) Discussion of the Crystal Structure of Compound 9................... Pages 16-17
} 

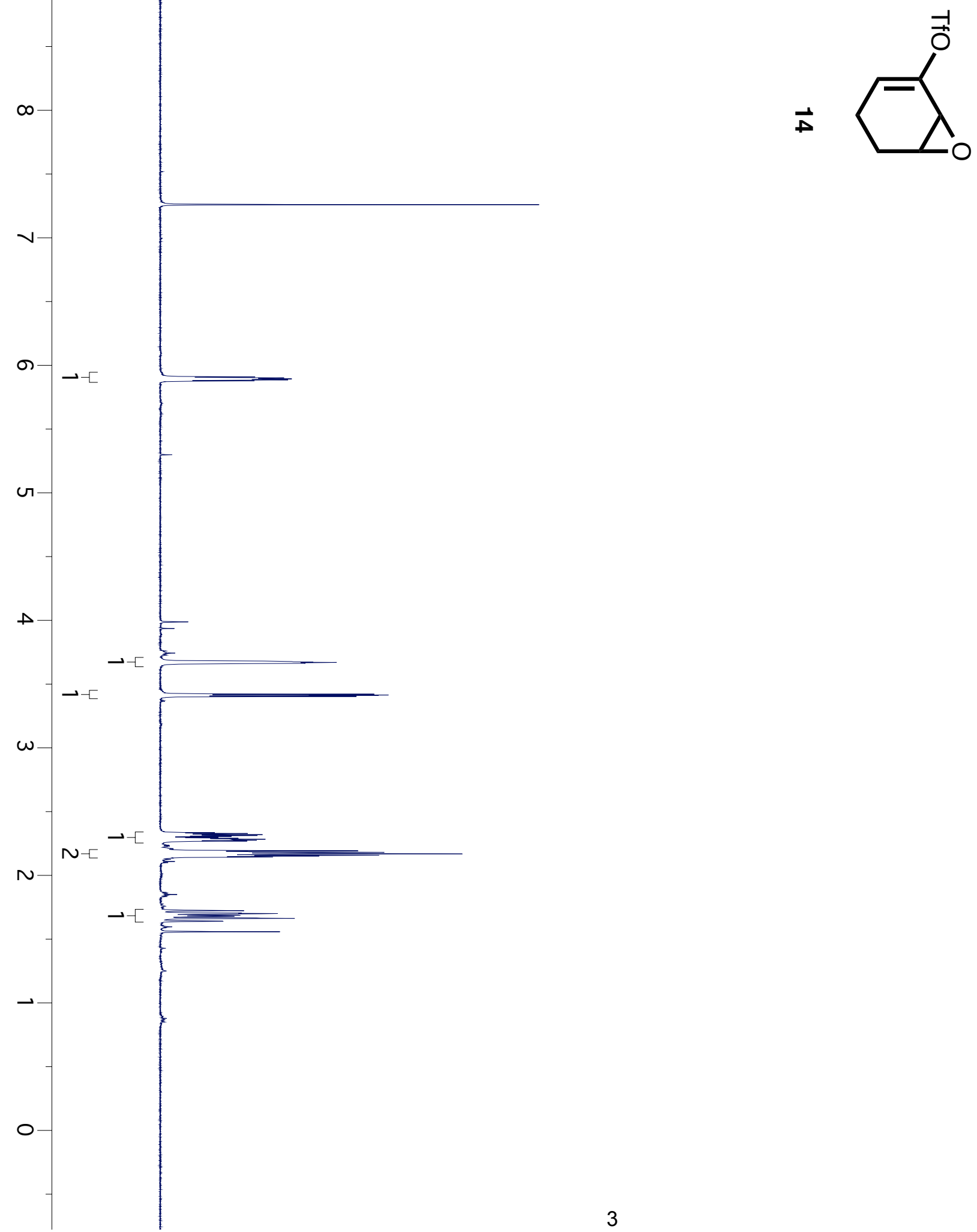


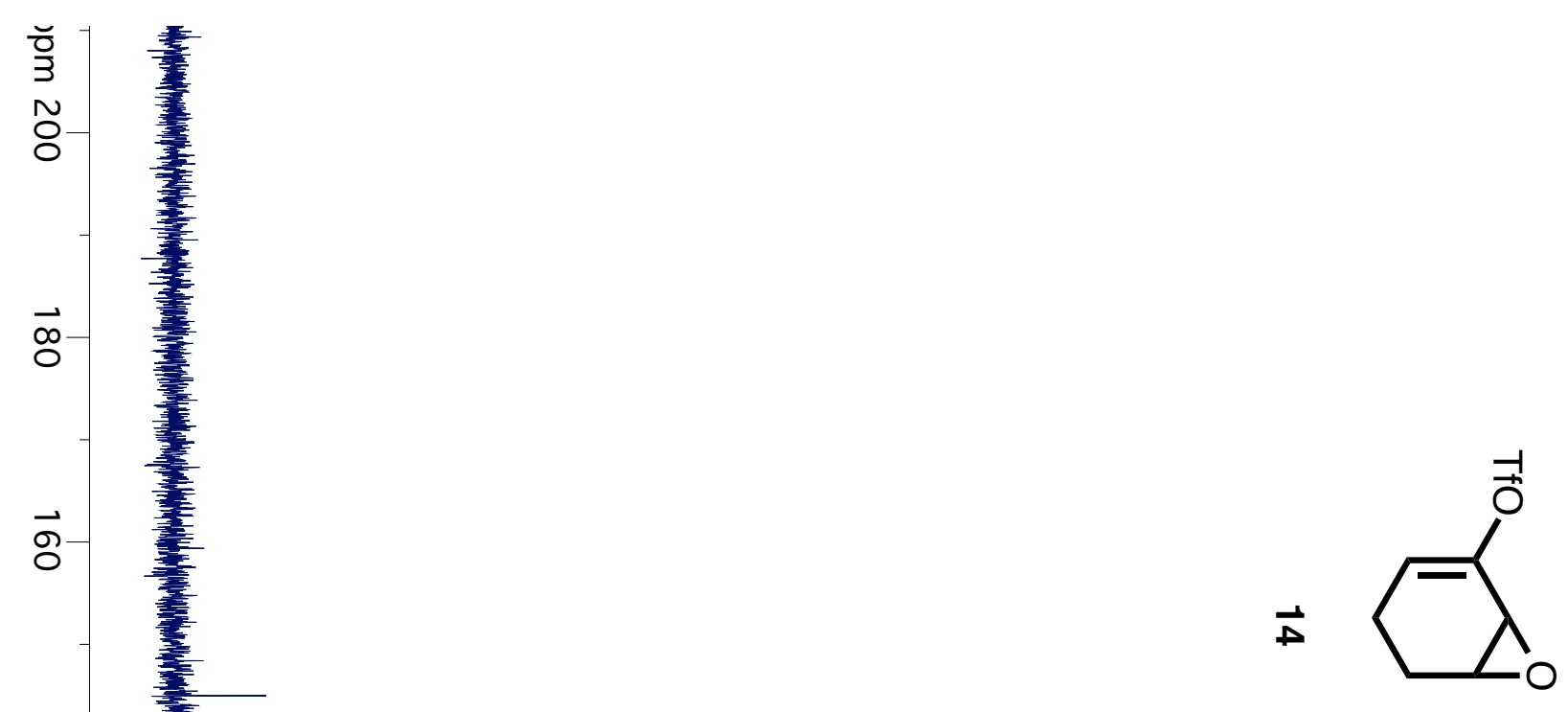

$\vec{a}$

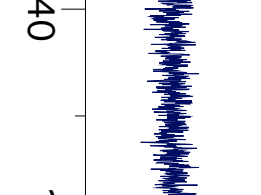

$\vec{\sigma}$

8 

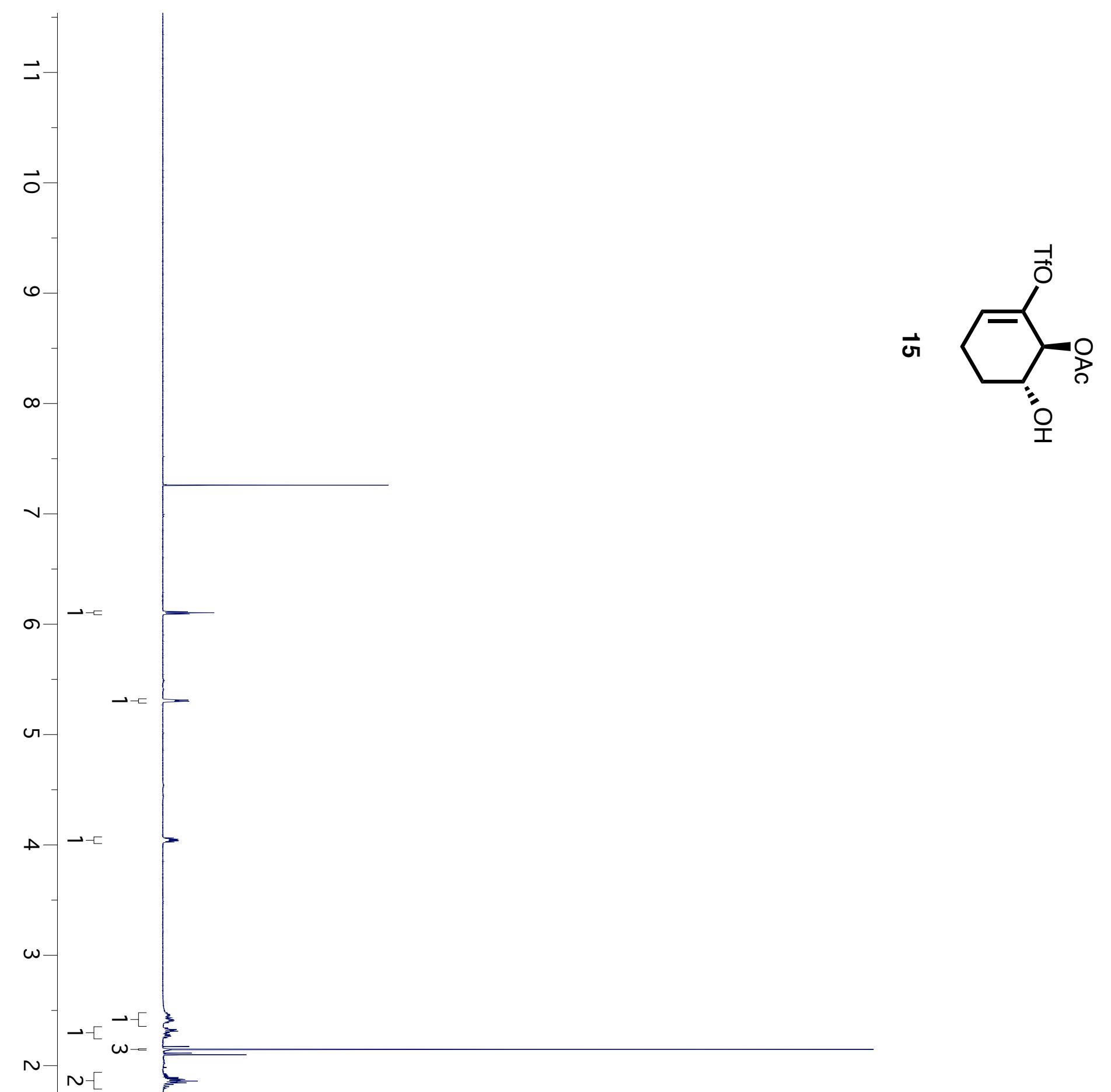

0

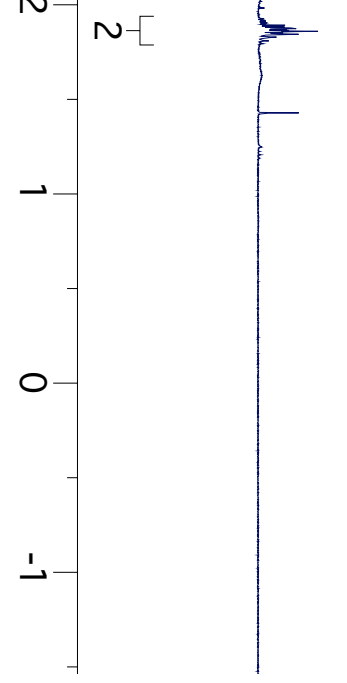




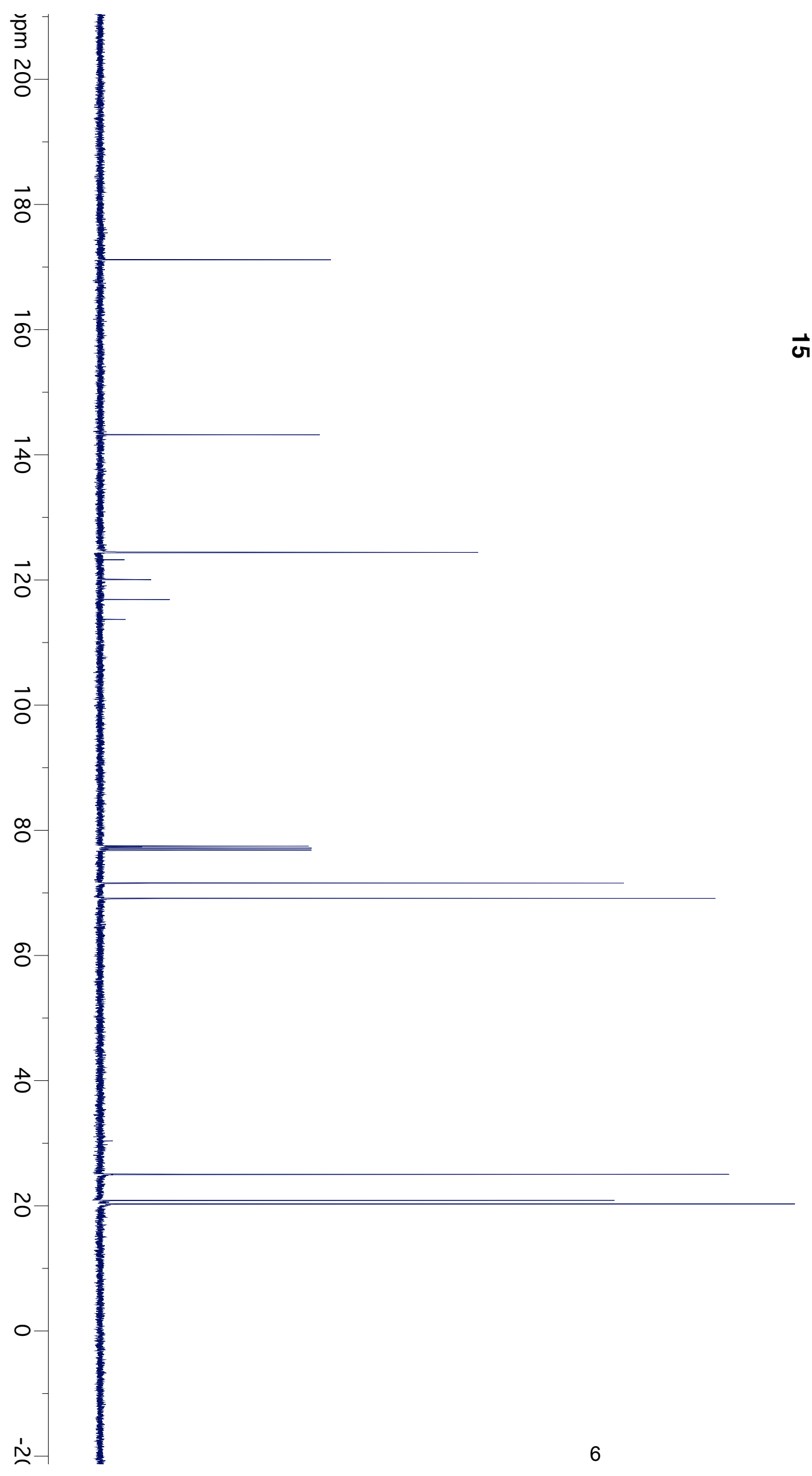




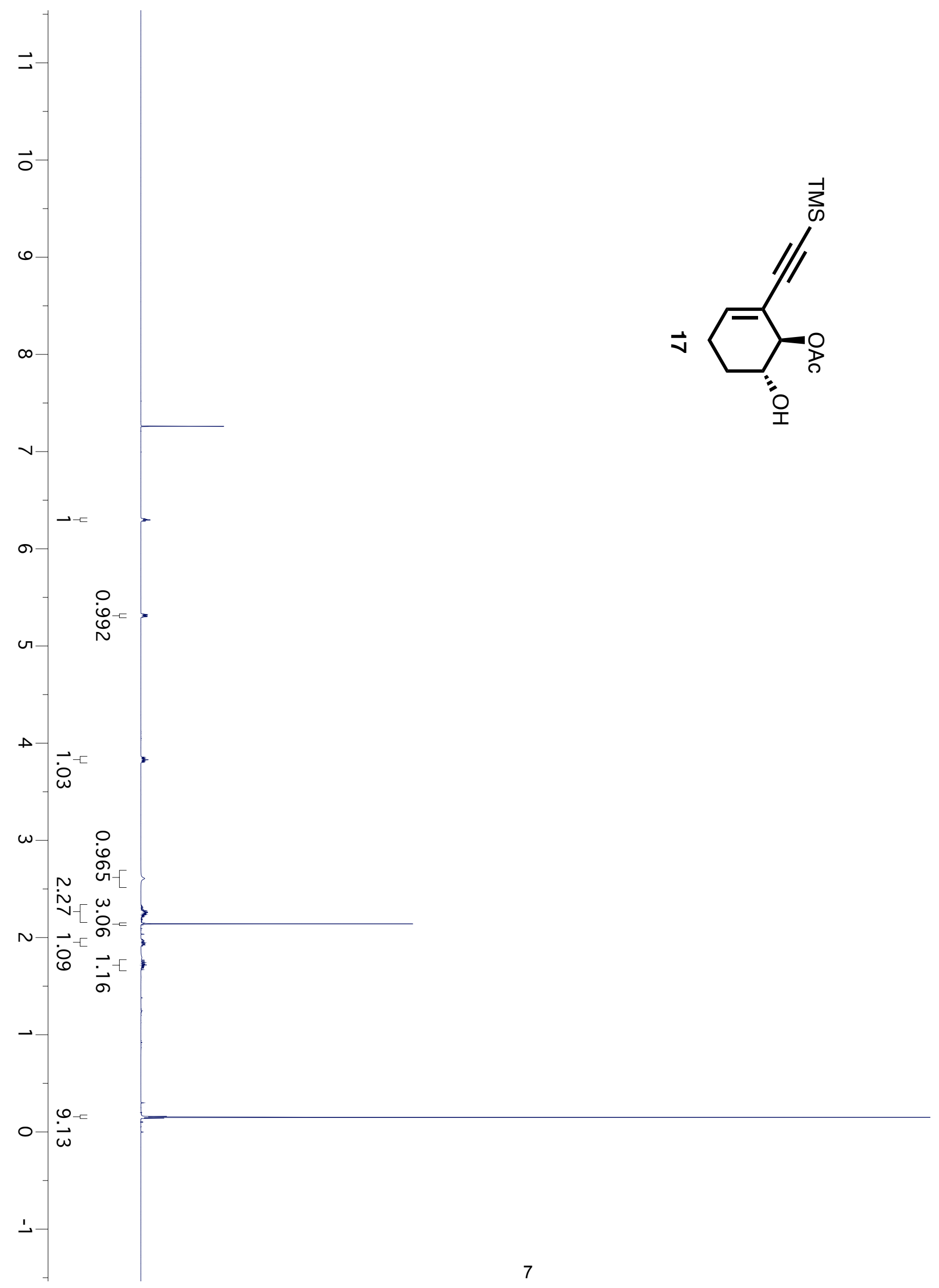




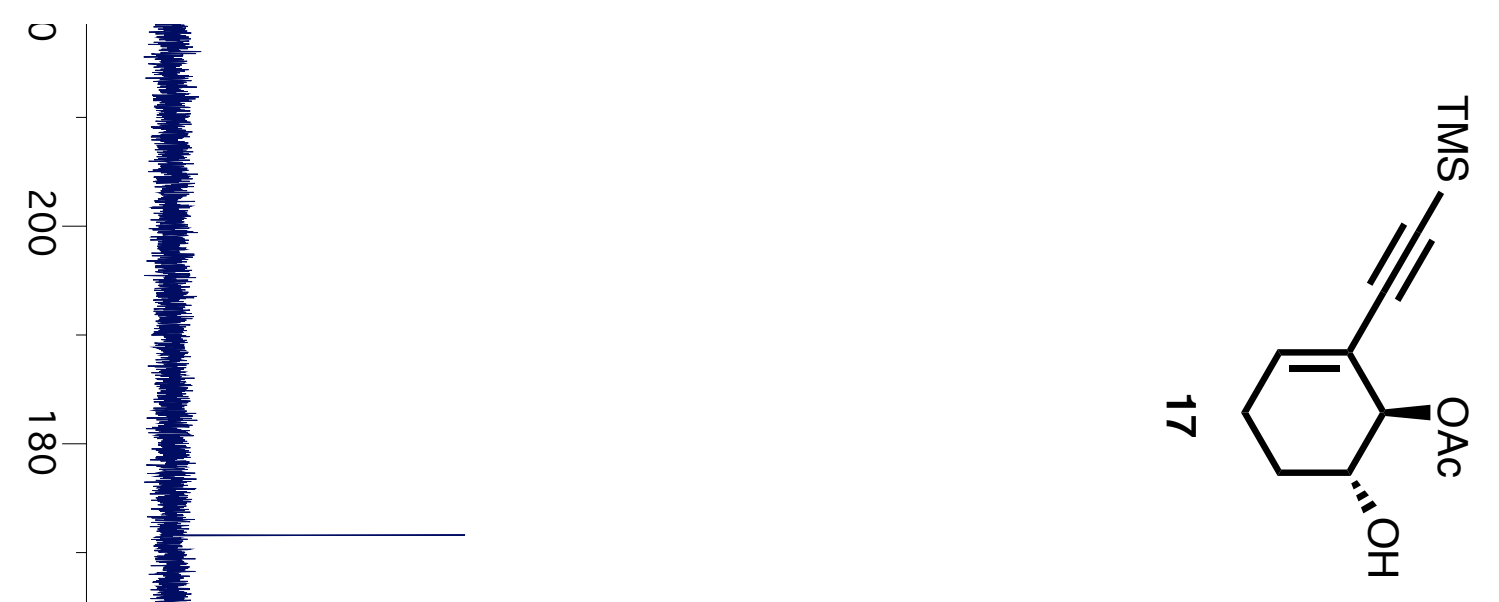




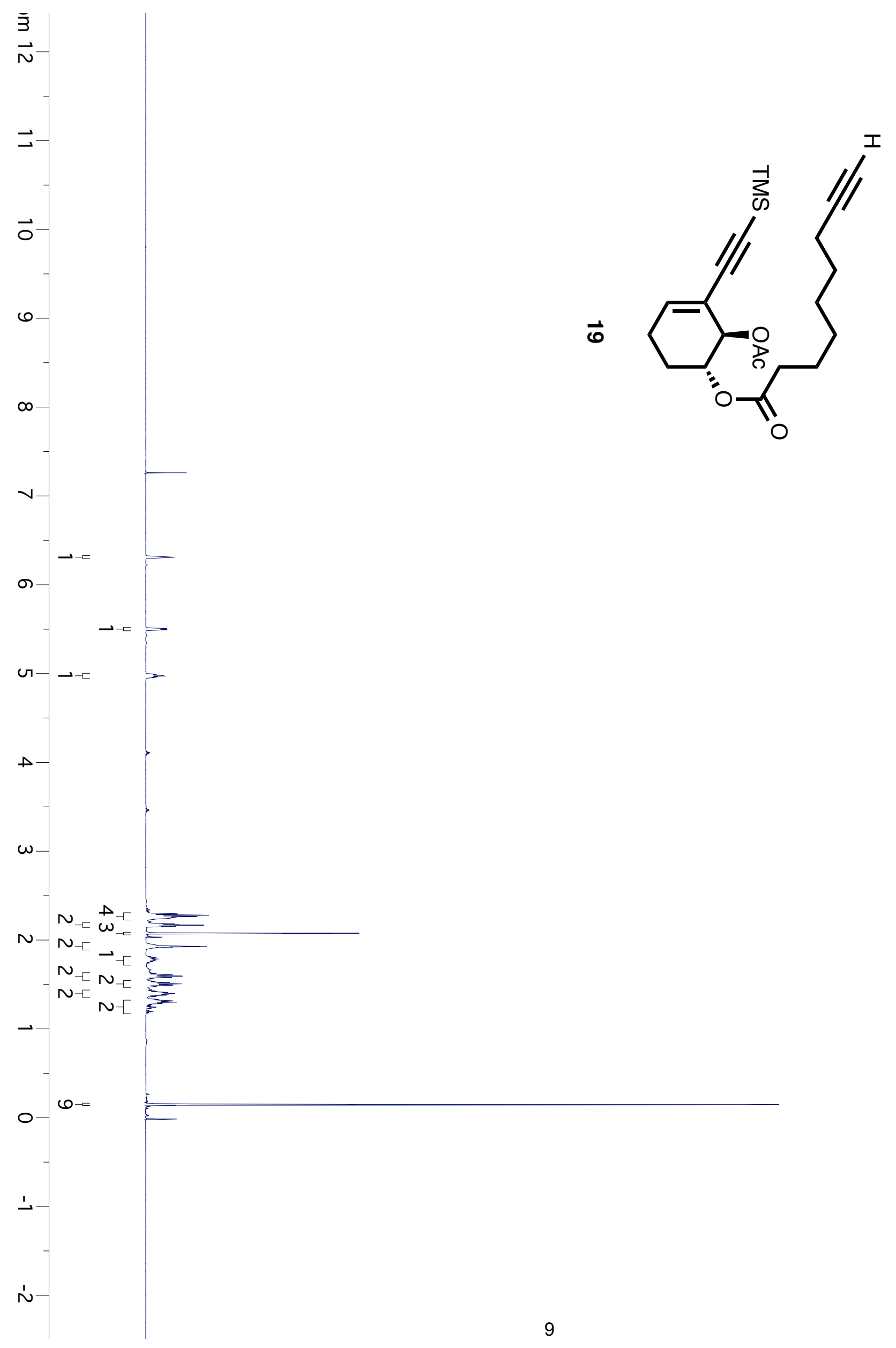




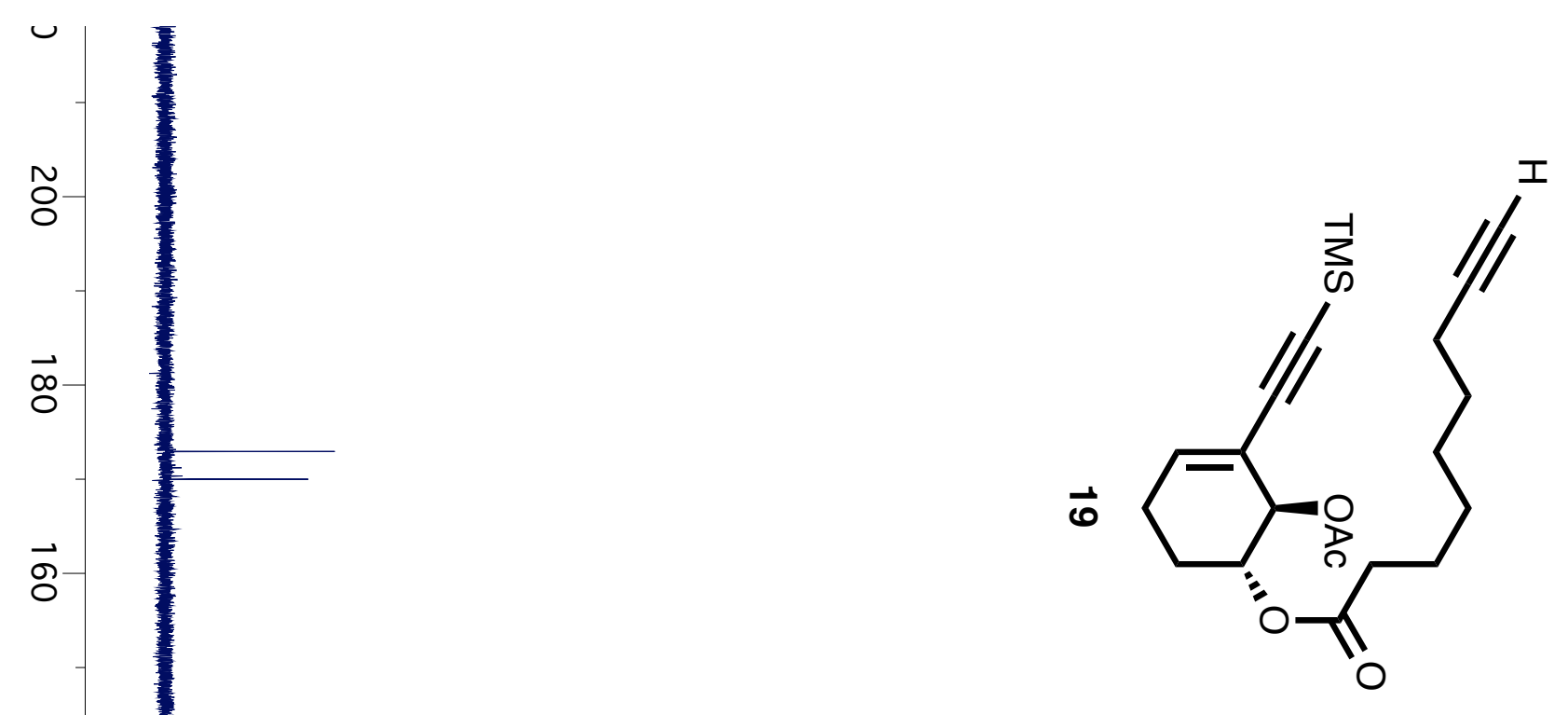




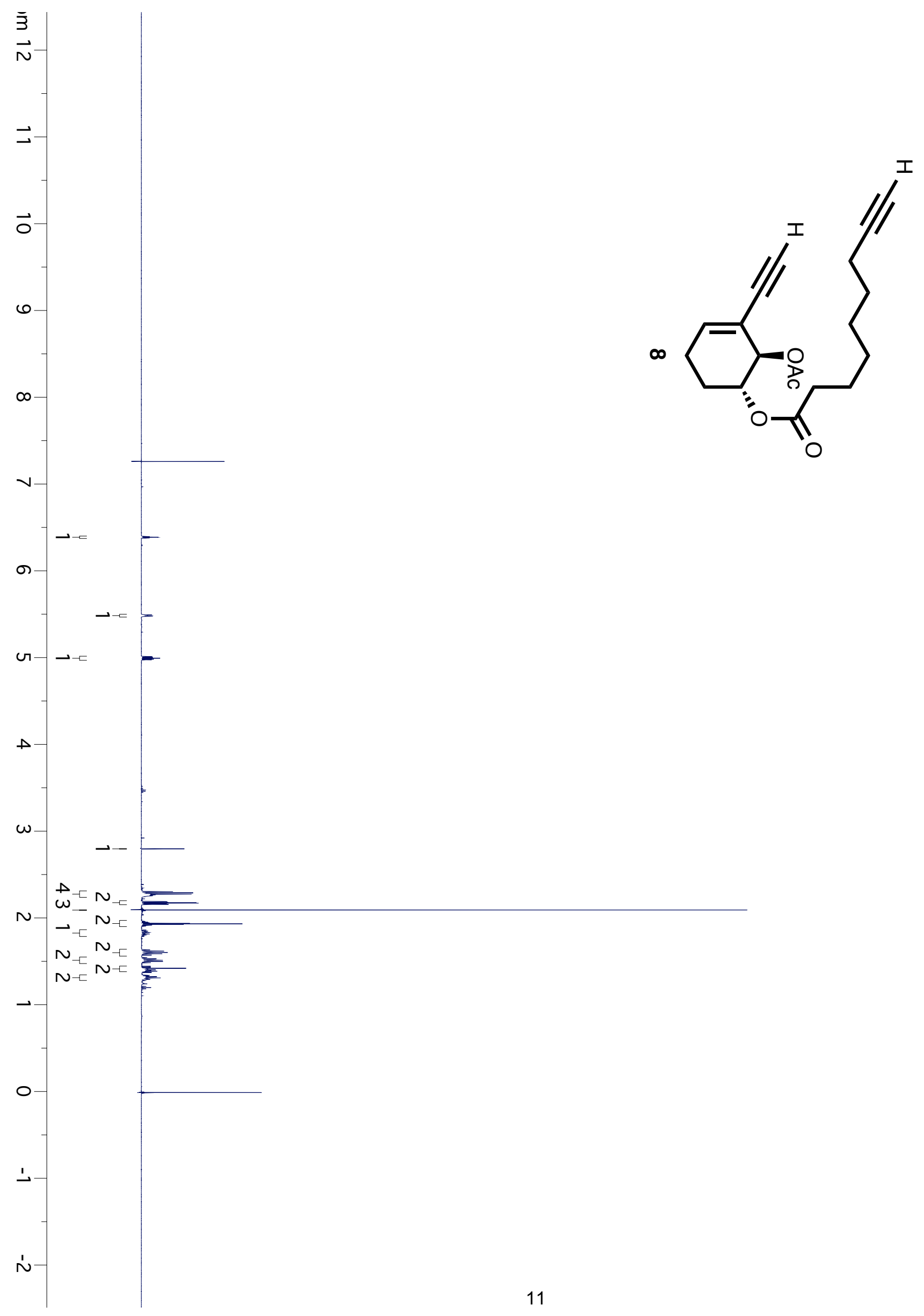




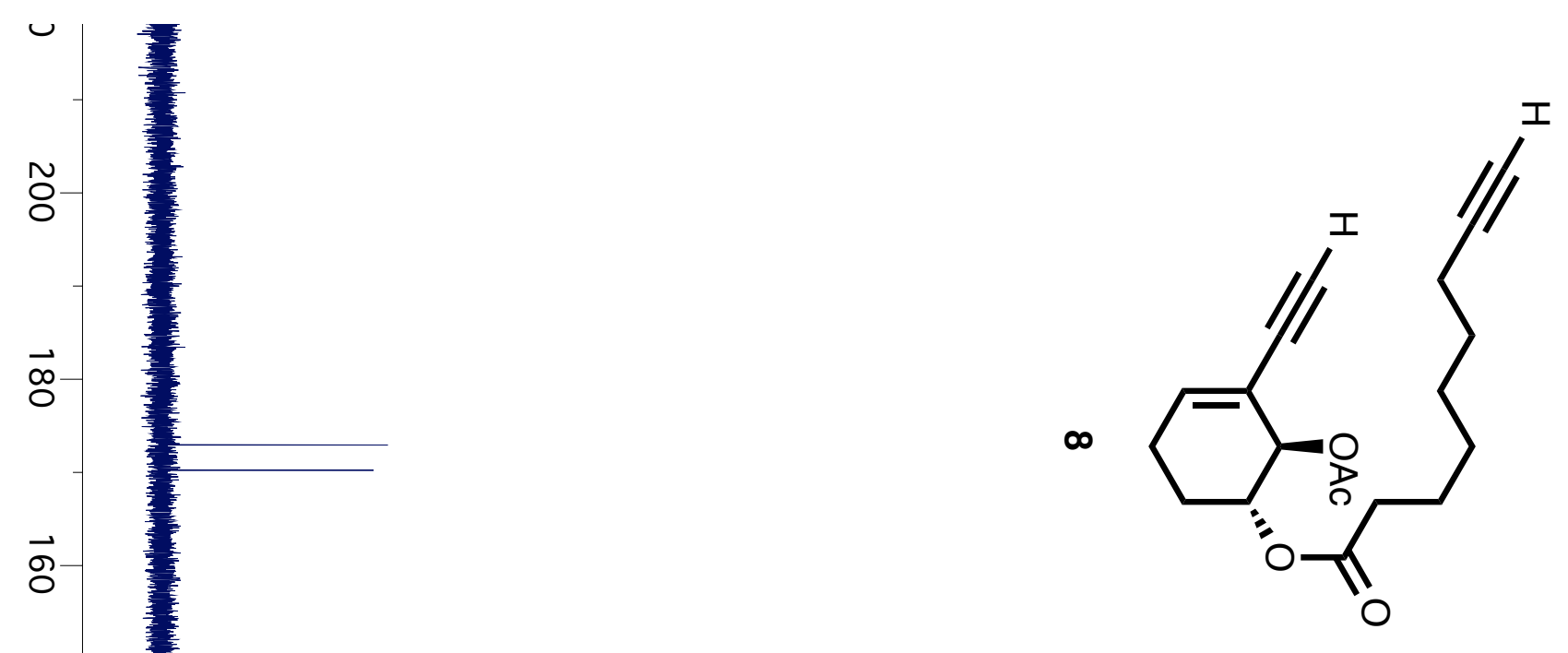

$\overrightarrow{0}$

$\vec{\circ}$

$\infty$

8

$\stackrel{1}{0}$

$\overrightarrow{0}$

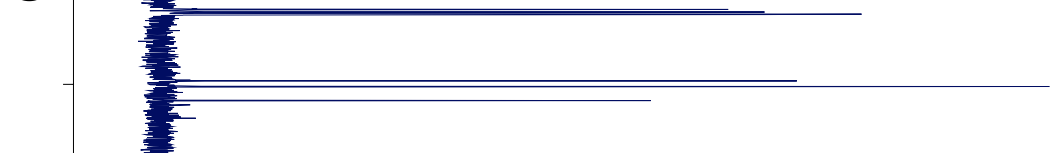

0

ก

กั 


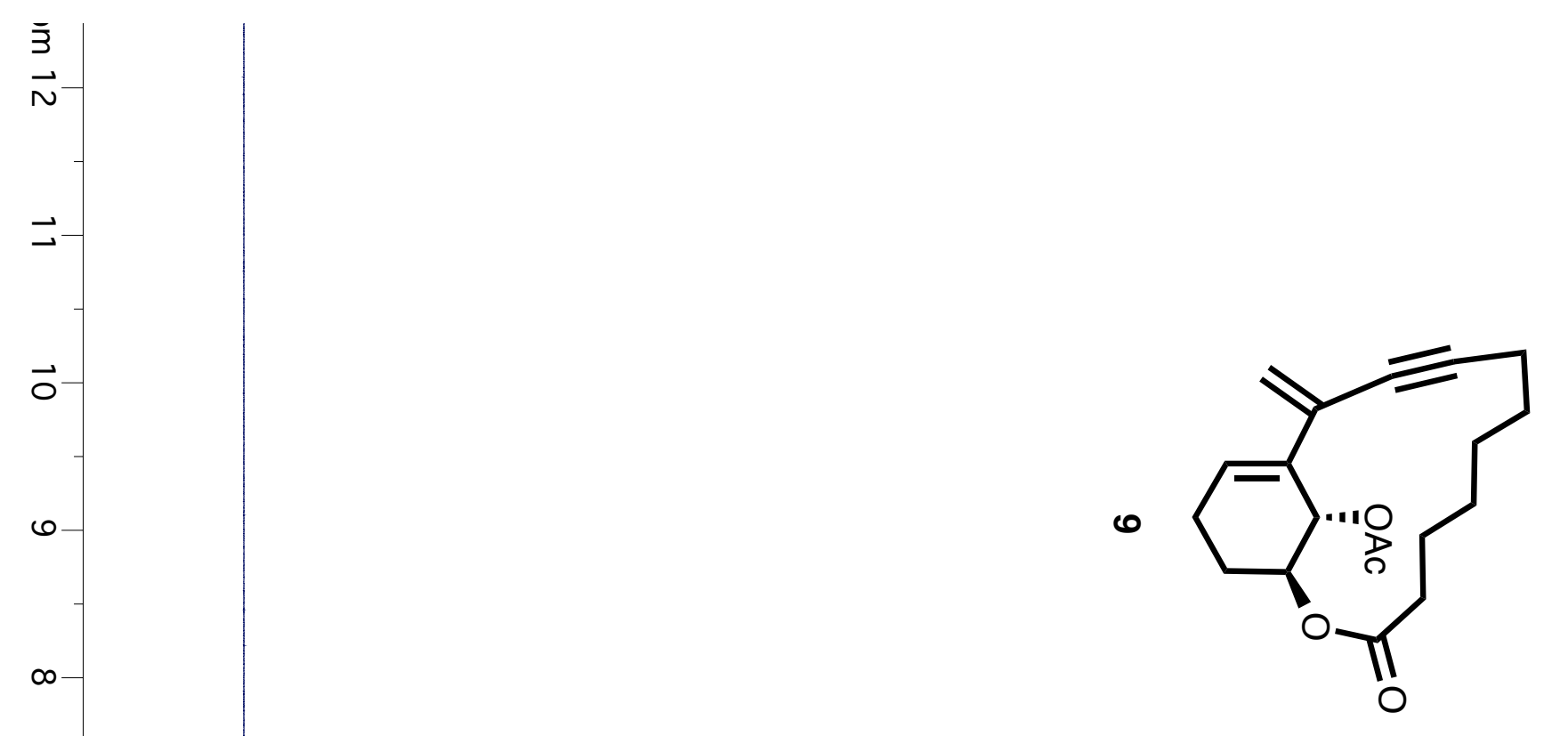




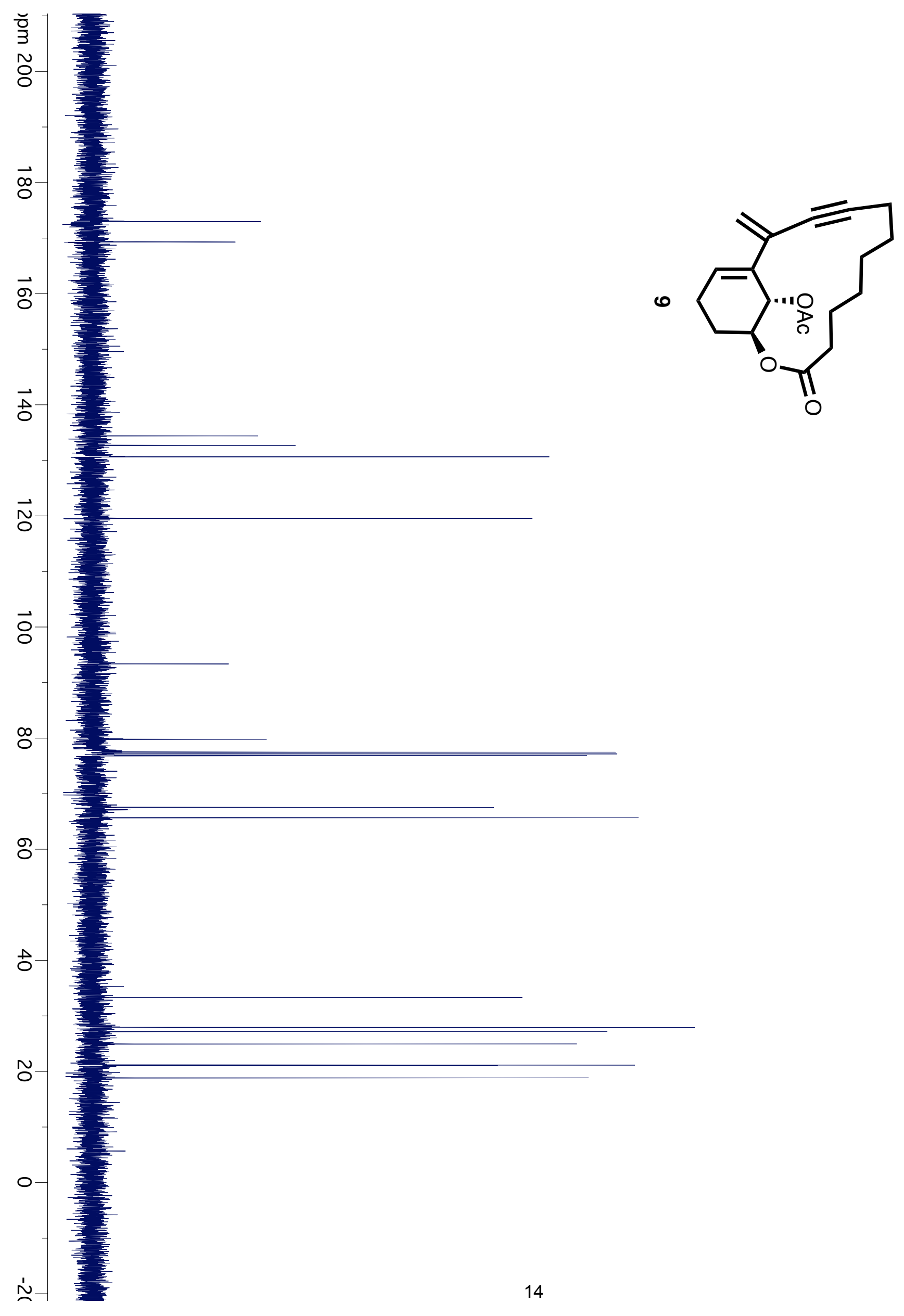


Thermal Ellipsoid Plot for Compound 9 (50\% Probability Level)

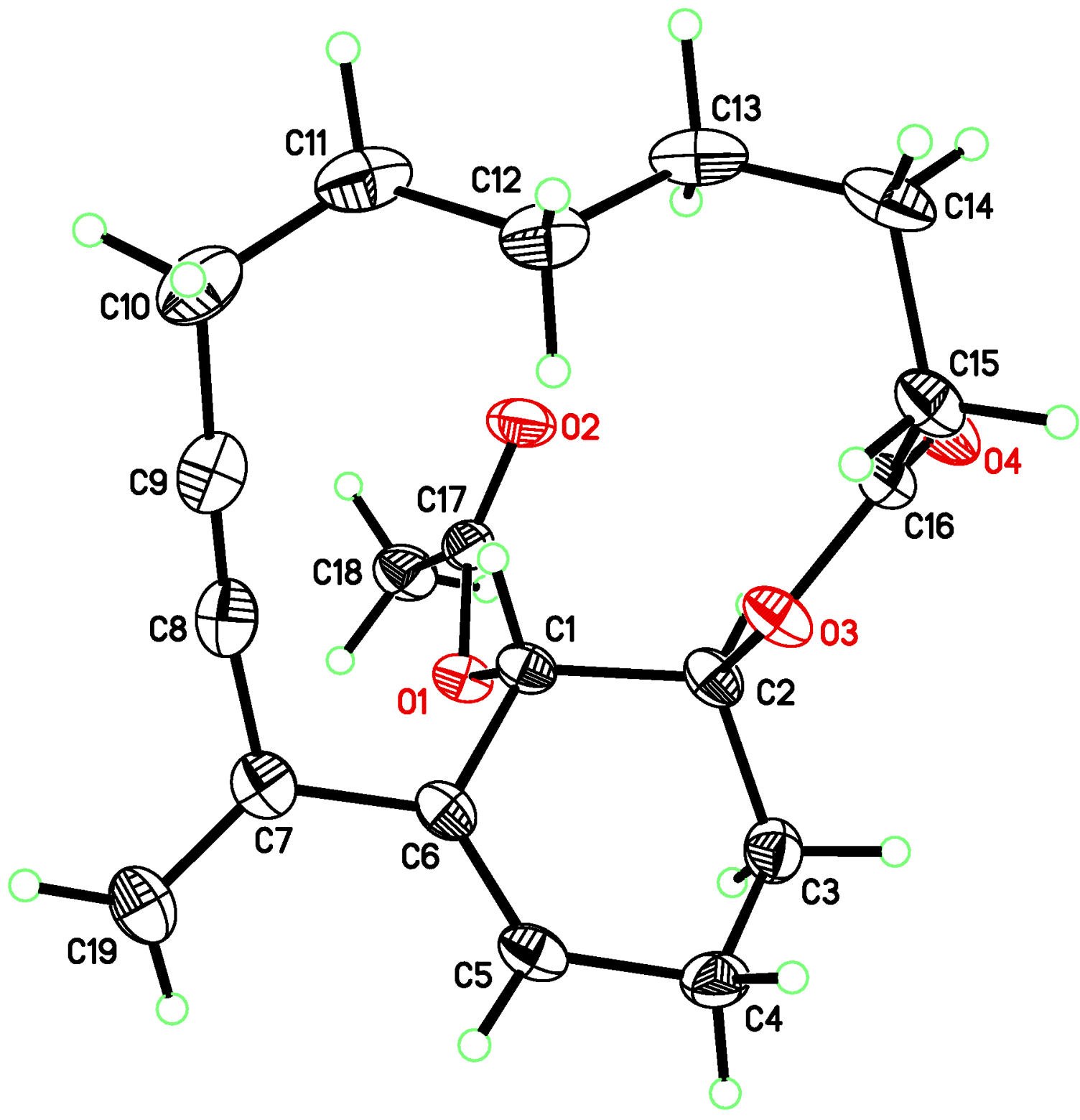




\section{DISCUSSION}

The compound crystallizes as colorless block-like crystals. There are four molecules of the compound in the unit cell of the primitive, centrosymmetric, monoclinic space group $\mathrm{P} 2{ }_{1} / \mathrm{n}$.

The structure of the compound is as expected (see Figures). The presence of the ethylene group was confirmed both by the bond distances and observation of electron density that is attributed to the two ethylinic hydrogen atoms.

Bond distances and angles within the molecule are as expected.

\section{CRYSTAL SUMMARY}

Crystal data for $\mathrm{C}_{19} \mathrm{H}_{24} \mathrm{O}_{4} ; \mathrm{M}_{\mathrm{r}}=316.38$; Monoclinic; space group $\mathrm{P} 21 / \mathrm{n} ; a=8.7733(11)$ $\AA ; b=14.7716(19) \AA ; c=13.7797(18) \AA ; \alpha=90^{\circ} ; \beta=106.983(2)^{\circ} ; \gamma=90^{\circ} ; \mathrm{V}=$ 1707.9(4) $\AA^{3} ; Z=4 ; T=120(2) \mathrm{K} ; \lambda(\mathrm{Mo}-\mathrm{K} \alpha)=0.71073 \AA ; \mu(\mathrm{Mo}-\mathrm{K} \alpha)=0.085 \mathrm{~mm}^{-1}$; $\mathrm{d}_{\text {calc }}=1.230 \mathrm{~g} . \mathrm{cm}^{-3} ; 26540$ reflections collected; 3788 unique $\left(\mathrm{R}_{\text {int }}=0.0371\right)$; giving $\mathrm{R}_{1}=$ $0.0375, \mathrm{wR}_{2}=0.0829$ for 3041 data with $[\mathrm{I}>2 \sigma(\mathrm{I})]$ and $\mathrm{R}_{1}=0.0513, \mathrm{wR}_{2}=0.0907$ for all 3788 data. Residual electron density $\left(\mathrm{e}^{-} . \AA^{-3}\right) \mathrm{max} / \mathrm{min}: 0.242 /-0.233$.

An arbitrary sphere of data were collected on a colorless block-like crystal, having approximate dimensions of $0.265 \times 0.132 \times 0.116 \mathrm{~mm}$, on a Bruker APEX-II diffractometer using a combination of $\omega$ - and $\varphi$-scans of $0.5^{\circ}$ [1]. Data were corrected for absorption and polarization effects and analyzed for space group determination. The structure was solved by intrinsic phasing methods and expanded routinely [2]. The model was refined by full-matrix least-squares analysis of $\mathrm{F}^{2}$ against all reflections. All nonhydrogen atoms were refined with anisotropic thermal displacement parameters. Unless otherwise noted, hydrogen atoms were included in calculated positions. Thermal parameters for the hydrogens were tied to the isotropic thermal parameter of the atom to which they are bonded $(1.5 \times$ for methyl, $1.2 \times$ for all others $)$.

\section{REFERENCES}

[1] Bruker AXS. (2008). APEX-2. Bruker-Nonius AXS, Madison, Wisconsin, USA.

[2] G. M. Sheldrick, Acta Cryst., 2008, A64, 112. 
Table 1. Crystal data and structure refinement.

Identification code

Empirical formula

Formula weight

Temperature

Wavelength

Crystal system

Space group

Unit cell dimensions

Volume

Z

Density (calculated)

Absorption coefficient $(\mu)$

$\mathrm{F}(000)$

Crystal color, habit

Crystal size

$\theta$ range for data collection

Index ranges

Reflections collected

Independent reflections

Completeness to $\theta=25.242^{\circ}$

Absorption correction

Max. and min. transmission

Refinement method

Data / restraints / parameters

Goodness-of-fit on $\mathrm{F}^{2}$

Final R indices [I $>2 \sigma(\mathrm{I})]$

$\mathrm{R}$ indices (all data)

Extinction coefficient

Largest diff. peak and hole su 1425

$\mathrm{C}_{19} \mathrm{H}_{24} \mathrm{O}_{4}$

316.38

$120(2) \mathrm{K}$

$0.71073 \AA$

Monoclinic

$\mathrm{P} 21 / \mathrm{n}$

$a=8.7733(11) \AA \quad \alpha=90^{\circ}$

$b=14.7716(19) \AA \quad \beta=106.983(2)^{\circ}$

$c=13.7797(18) \AA \quad \gamma=90^{\circ}$

1707.9(4) $\AA^{3}$

4

$1.230 \mathrm{~g} . \mathrm{cm}^{-3}$

$0.085 \mathrm{~mm}^{-1}$

680

colorless, block

$0.265 \times 0.132 \times 0.116 \mathrm{~mm}^{3}$

2.071 to $27.198^{\circ}$

$-11 \leq \mathrm{h} \leq 11,-18 \leq \mathrm{k} \leq 18,-17 \leq 1 \leq 17$

26540

$3788\left[\mathrm{R}_{\text {int }}=0.0371\right]$

$100.0 \%$

Semi-empirical from equivalents

0.7455 and 0.6994

Full-matrix least-squares on $\mathrm{F}^{2}$

3788 / 0 / 209

1.015

$\mathrm{R}_{1}=0.0375, \mathrm{wR}_{2}=0.0829$

$\mathrm{R}_{1}=0.0513, \mathrm{wR}_{2}=0.0907$

$\mathrm{n} / \mathrm{a}$

0.242 and $-0.233 \mathrm{e}^{-} . \AA^{-3}$ 